\title{
CASA E FAMÍLIA NA GEOGRAFIA: ESTRATÉGIAS ESPACIAIS DE MULHERES SEM-TETO NA CONSTRUÇÃO DO LAR ${ }^{1}$
}

- MARIANNA FERNANDES MOREIRA²

Resumo: 0 presente trabalho traz como foco uma habitação coletiva muito peculiar: uma ocupação de sem-teto denominada Ocupação Quilombo das Guerreiras. A abordagem proposta tem como objetivo tratar da geografia da casa e da família a partir das práticas e estratégias espaciais de mulheres sem-teto na construção do lar. Na primeira parte do artigo, discorro sobre a família como mecanismo de governo e sobre as particularidades do exercício do poder sobre as classes populares. 0 objetivo desta parte é problematizar a noção de família nuclear e apontar como a intervenção estatal na moradia do pobre urbano será uma forma de induzir comportamentos e valorizar determinados costumes para que se configure um núdeo familiar. Em seguida, buscarei abordar a tensão indivíduo-família-Coletivo que emerge por se tratar de um movimento que se sustenta em fidelidades tecidas por vínculos afetivos e relações sociais de caráter comunitário, e que termina por permear os espaços privados, o convívio familiar e o cuidado com as crianças. Por fim, volto a atenção à construção material da casa e às práticas espaciais que constroem, de diferentes formas, um "território íntimo" no qual a individualidade da mulher pode se expressar para além do espaço doméstico.

Palavras-chave: sem-teto, casa, familia, lar, território íntimo, geografia feminista.

Os estudos sobre a família e a casa na Geografia

O trabalho aqui presente traz como foco uma habitação coletiva muito peculiar: uma ocupação de sem-teto. Trata-se de uma ocupação com aproximadamente 50 famílias e quase seis anos de existência denominada Ocupação Quilombo das Guerreiras, 
localizada na Zona Portuária do Rio de Janeiro. No entanto, o enfoque que gostaria de conferir ao estudo não tem como objetivo analisar as estratégias de resistência à especulação imobiliária ou a consistência política da organização dos moradores. Tais estudos são certamente importantes ${ }^{3}$, porém, creio que ao penetrarmos a intimidade dos espaços domésticos e das relações familiares, poderemos começar a compreender melhor como a ocupação é efetivamente vivenciada por seus moradores. Isso não significa ignorar as particularidades da organização política formal adotada por eles, mas abordá-la somente na medida em que ela age diretamente sobre a convivência cotidiana. Nosso objetivo é fazer emergir a ampla gama de conflitos, tensões e estratégias mobilizadas pelos moradores e moradoras que, não raro, terminam negligenciadas nos estudos sobre os movimentos sociais. Nesse sentido, a dimensão do compartilhamento cotidiano e, por conseguinte, os loci das relações familiares e de vizinhança ganham especial relevância para o presente trabalho.

A preocupação da Geografia com as relações familiares, com o lar e com a casa esteve, com frequência, associada, de uma forma ou de outra, com o papel do governo e com o planejamento urbano, seja na abordagem ligada ao sociólogo e engenheiro Frédéric Le Play, ou na perspectiva neopositivista representada por William Bunge e Robert Bordessa (1975). Le Play foi, segundo Dickinson (citado por CAPEL, 1981), um dos construtores da Geografia moderna.

$$
\text { Segundo Capel (1981), Le Play }
$$
estava particularmente interessado em compreender o que os operários faziam durante as horas livres, nos espaços domésticos (espaços de reprodução). Le Play acreditava que o lugar de residência influenciava a forma de se obter a subsistência e o tipo de trabalho realizado e, este, por sua vez, afetava a organização, as práticas e as formas de vida familiar. Capel (1981) ressalta que a Sociologia de Le Play talvez seja o exemplo mais surpreendente de uma ideologia de classe fundada em pesquisas empíricas minuciosas sobre as famílias operárias. Segundo o autor, suas ideias foram bastante influentes na França, e Vidal de La Blache, depois, desenvolveu as ideias de Le Play para construir o conceito de "gênero de vida".

William Bunge e Robert Bordessa (1975), em seu livro The Canadian Alternative, por outro lado, preocupam-se com a geografia das crianças. Os autores adotam uma perspectiva que busca a possibilidade de uma reestruturação democrática dos governos urbanos, e 
dedicam-se, particularmente, a pensar formas de organização do espaço urbano que possam, ao mesmo tempo, conferir mais liberdade à mobilidade da criança e protege-la dos perigos da cidade. Segundo os autores, as crianças apresentam características de territorialidade, visto que elas tendem a se agrupar em determinados espaços da cidade, como os parques, por exemplo. Contudo, os autores também destacam o papel dos pais na limitação do território da criança, visto que, pelo menos até uma certa idade, os pais procuram manter seus filhos em seu campo de visão.

Hoje, porém, há uma retomada da família, do lar e da casa como objeto de estudo da Geografia, especialmente a partir das contribuições de geógrafas feministas, como Geraldine Pratt, Doreen Massey e Allison Blunt. Há também uma revista especializada chamada Children's Geographies, que além de conter artigos sobre a geografia de crianças e jovens, também se ocupa de suas famílias, e conta com contribuições de geógrafos renomados como Gill Valentine e Chris Philo. Segundo Allison Blunt (2006), a geografia marxista esteve focada na produção, nos locais e nos processos de trabalho. Assim, o lar, a casa e a família, quando tratados, eram relegados a segundo plano e reduzidos à sua relação com a esfera do trabalho, isto é, apreendidos como espaço de reprodução social. Os geógrafos humanistas, no entanto, conferiram mais atenção ao lar, diferenciando-o da casa (que pode ser facilmente substituída), e apreendendo-o como "centro insubstituível de significância" (RELPH, 1976, p. 39).

As geógrafas feministas, entretanto, teceram críticas importantes aos humanistas. Gillian Rose (1993), por exemplo, argumenta que a caracterização do lar dos geógrafos humanistas como base essencial da identidade humana é masculina, ou seja, está amparada pela experiência do homem e não da mulher, visto que o lar pode muito bem ser um lugar de opressão e violência. Recentemente, o pensamento feminista sobre a família e o lar tem se inspirado no pós-estruturalismo e no póscolonialismo para questionar, inclusive, as perspectivas feministas de mulheres brancas, heterossexuais e europeias, que concebem o lar como, predominantemente, um local de opressão (BLUNT \& DOWLING, 2006). bell hooks (1991), por exemplo, argumenta que as mulheres negras não podiam aprender a amar e a respeitar a si mesmas no interior da cultura da supremacia branca. Segundo ela, é na casa, no lar (homeplace), no espaço criado e mantido pelas mulheres negras, que elas tinham a oportunidade de crescer e de 
cultivar seus espíritos. Assim, as geógrafas feministas que se inspiram nos estudos póscoloniais apreendem o lar como lugar de resistência e de opressão e levam em conta a multiplicidade de formas de vivenciar o lar, reconhecendo, portanto, a sua fluidez como conceito, metáfora e experiência (BLUNT\& DOWLING, 2006).

$\mathrm{O}$ que o pós-colonialismo tem em comum com a pesquisa feminista é que ambos buscam dar voz àqueles que são geralmente anulados por um discurso hegemônico. $\mathrm{O}$ apelo ao descentramento da Europa busca construir uma história que não seja simplesmente um episódio da história europeia. Ao mesmo tempo, as feministas procuram afirmar que, não só a teoria é local (como afirmava Foucault), mas que ela também é generificada, racializada e sexualizada. Por isso, tanto a teoria feminista quanto os estudos pós-coloniais tem em comum uma clara objeção ao universalismo. Eles denunciam o universalismo como discurso dominante e opressor, mas o que importa, mesmo do ponto de vista estritamente acadêmico, é que eles revelam a multiplicidade de perspectivas que é suplantada por esse universalismo. Por isso, trata-se em ambos os casos de teorias preocupadas com a relacionalidade. Isto é, não partir de um estudo do ser (da colônia, da mulher, da família etc.), mas compreender como, em cada conjuntura, essas categorias são construídas socialmente.

Portanto, o propósito de construir uma teoria feminista não é por revanche ou denúncia do machismo existente, mas sim, um apelo ao fato de que há outras formas de se apreender as relações sociais e, por conseguinte, o seu espaço. Além disso, não só a teoria feminista não precisa se restringir ao pensamento de "mulheres pesquisadoras", como é extremamente importante que ela não o faça. Quando se critica uma forma de racionalidade branca, masculina, heterossexual, europeia; é devido ao fato de que esse foi o olhar hegemônico não só dentro da Geografia, mas no interior de outras ciências sociais também.

Os estudos feministas, estudos sobre gênero, vão muito além de se estudar/analisar o que é ser "mulher" (ou "feminino"). Neste sentido, a teoria feminista tem muito mais a ver com uma teoria dissidente, desviante, do que propriamente com uma proposta centrada na mulher generificada. Deste modo, mais importante do que colocar a questão sobre o que há de dissidente nas relações de gênero e nas práticas cotidianas das ocupantes, seria fazer a questão inversa, ou seja, o que há de feminino nas práticas dissidentes encontradas na ocupação 
estudada? Assim, ao invés de buscar um discurso feminista no movimento dos semteto, ou práticas espaciais que invertem posicionamentos de gênero (como a mulher chefe de família em oposição à dona de casa etc.), opto por dedicar maior atenção aos discursos e práticas efetivamente produzidas e concretamente realizadas, não no sentido de buscar o ponto no qual as ocupantes se insurgem ou se resignam ao poder patriarcal da família mononuclear, mas para entender a forma como elas racionalizam e agem sobre a materialidade dada.

$\mathrm{Na}$ primeira parte do artigo, discorro sobre a família como mecanismo de governo e sobre as particularidades do exercício do poder sobre as classes populares. Nosso objetivo nesta parte é problematizar a noção de família nuclear e apontar como a intervenção estatal na moradia do pobre urbano será uma forma de induzir comportamentos, valorizar determinados costumes para que se configure um núcleo familiar. A intervenção estatal atua sobre a moradia popular no sentido de reduzir a multiplicidade dos modos de habitar aos preceitos gestados no interior da burguesia. Assim, a equação da habitação popular foi buscada na convergência de três objetivos: organizar um espaço que seja suficientemente amplo para ser higiênico; pequeno o bastante para que só a família possa viver nele; e distribuído de tal maneira que os pais possam vigiar os filhos (DONZELOT, 1986[1980]).

Neste sentido, a organização das relações familiares é buscada através da organização espacial da casa. Porém, a literatura (nacional e internacional), ao falar de forma coerente deste impulso organizador, refere-se, quase que exclusivamente, às classes operárias, em seu sentido clássico. Portanto, pergunto se podemos ver os mecanismos de poder que incidem sobre uma população de trabalhadores que vivem uma constante instabilidade de sua moradia. Assim, nosso foco será direcionado para as famílias de uma ocupação de sem-teto localizada no centro da cidade do Rio de Janeiro: a Ocupação Quilombo das Guerreiras. Será que os três objetivos mencionados acima exercem algum efeito sobre famílias de semteto? Ou seja, dada as condições materiais em que estas famílias estão inseridas, como aqueles três objetivos podem ser alcançados?

A literatura também aponta que a estratégia de familiarização das camadas populares utiliza como suporte principal, a mulher, e lhe associa um certo número de instrumentos e aliados. Mas o principal 
instrumento que ela recebe é a habitação "social", e seu papel consiste em afastar estranhos e mandar entrar o marido e, sobretudo, os filhos. Mas será que esse impulso de estabilização das relações familiares atua nessa classe que não tem moradia fixa, isto é, que não obteve uma habitação social? Será que mesmo a habitação precária, "inadequada", "antihigiênica", de um só cômodo, serve como objeto e instrumento dessa estabilização? Será que essas mulheres de uma ocupação de sem-teto também atuam como um agente da estabilização/normalização? Como utilizam a moradia como instrumento?

Em seguida, buscarei abordar a tensão indivíduo-família-Coletivo que emerge por se tratar de um movimento que se sustenta em fidelidades tecidas por vínculos afetivos e relações sociais de caráter comunitário, e que termina por permear os espaços privados, o convívio familiar e o cuidado com as crianças. $\mathrm{O}$ fato de tratar-se de uma habitação coletiva, onde a intimidade da vida doméstica é colocada em cheque tanto pela atuação do Coletivo (intervindo na vida familiar sempre que considera necessário) quanto pela precariedade do espaço físico (tornando públicas as conversas e conflitos existentes no interior do lar), contribui para a configuração de formas específicas de relacionalidade.

$$
\text { Por fim, volto a atenção à }
$$
construção material da casa e às práticas espaciais que constroem, de diferentes formas, um "território íntimo" no qual a individualidade da mulher pode se expressar para além do espaço doméstico. Neste sentido, como a mulher expressa sua sexualidade, sem expor os filhos à sua intimidade, mas ao mesmo tempo, sem dispor de um quarto seu, afastado do olhar dos filhos, espaço este que chamo aqui de "territórios íntimos"? Como faz para libertar-se, mesmo que por um instante, das imposições identitárias do espaço doméstico, que acompanham o papel de mãe, dona de casa ou chefe de família?

Portanto, o presente artigo busca compreender como as mulheres de uma ocupação de sem-teto no Rio de Janeiro, mesmo vivendo uma situação de moradia instável, elaboram estratégias criativas para contornar as parcas condições materiais em que vivem, sem deixar de expressar sua individualidade e sem ser, por definição, nem autônomas, nem dominadas (ou integradas) em termos absolutos. 
Problematizando a família nuclear

1. A historicização da família nuclear e

o governo através da família

"O mundo familiar mostra-se numa vibrante variedade de formas de organização, com crenças, valores e práticas desenvolvidas na busca de soluções para as vicissitudes que a vida vai trazendo. Desconsiderar isso é ter a vã pretensão de colocar essa multiplicidade de manifestações sob a camisade-força de uma única forma de emocionar, interpretar, comunicar." (SZYMANSKI, 2003 [1995], p. 27).

Luiz Fernando Dias Duarte (1995) argumenta que o que chamamos de família no Ocidente moderno é exclusivo da nossa cultura e baseado em agenciamentos de valores próprios. Em seu artigo, Duarte alerta para a naturalização da família nuclear, apontando a negação pelo senso comum desse processo como socialmente construído e o mascaramento da relativa arbitrariedade dessas relações baseadas nos afetos domésticos.

Alguns elementos têm sido indicados, por diferentes autores, como importantes para compreender a força desse modelo idealizado em sociedades contemporâneas. Um desses elementos vem da valorização feita da família nuclear como resultado e sinônimo de processos de modernização das sociedades. (VIANNA, 2002). Na realidade, como nos mostra Luiz Fernando Dias Duarte (1995), este seria um dos efeitos da individualização nas sociedades modernas, inseparável das características do modelo de família - a fragmentação, a redução das unidades sociais à sua forma mais "indivisível", fazendo com que a própria "família nuclear" possa corresponder a uma espécie de "indivíduo coletivo".

Jacques Donzelot busca compreender como se deu a transformação da família a partir do século XVIII, e como essas transformações são trabalhadas nas diferentes classes sociais. A questão principal de Donzelot é desvendar como a família funciona como objeto de governo. Segundo ele, enquanto a constituição da família burguesa se dá através de um retraimento tático - permitindo-lhe depois retornar ao campo social com mais força, para aí exercer diversos controles e patrocínios -, a família popular se conforma a partir de uma redução de cada um de seus membros aos outros, numa relação circular de vigilância contra as tentações do exterior. "Ela realiza suas novas tarefas 
educativas à custa de uma perda de sua coextensividade com o campo social de uma separação de tudo aquilo que a situava num campo de forças exteriores. Isolada, ela se expõe, doravante, à vigilância de seus

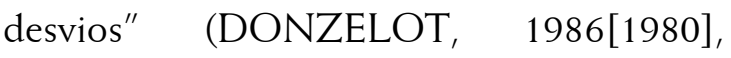
p.47).

O referido autor considera que é ainda mais significativa a diferença de posições táticas em que se encontram a mulher burguesa e a mulher popular. Segundo o autor, através da revalorização das tarefas educativas se estabelece, para a mulher burguesa, uma nova continuidade entre as suas atividades familiares e suas atividades sociais. Ela abre para si um campo profissional na difusão das novas normas assistenciais e educacionais. Pode, ao mesmo tempo, ser suporte de uma transmissão do patrimônio no interior da família e instrumento de irradiação cultural no exterior. A mulher do povo possui, por natureza, um trabalho antagônico com o seu status materno. Este, muitas vezes representa uma necessidade, mas é sempre obstáculo à realização de sua função de guardiã do lar. Para ela, não se trata de irradiação: sua missão é, ao contrário, velar por uma retração social de seu marido e de seus filhos. É dela, da regularização que impõe, que depende a transmissão de um "patrimônio social" que permanece, quase sempre, exterior a família, cuja gestão escapa à família e do qual o operário não pode dispor enquanto viver, já que só obtém com sua própria deterioração e morte. (DONZELOT, 1986[1980], p.48).

E quanto às crianças? $\mathrm{O}$ autor afirma que, nas famílias burguesas, empenham-se em dar a forma de uma libertação protegida, de um resgate dos medos e pressões comuns. Em torno desta família, traça-se um cordão sanitário que delimita seu campo de desenvolvimento: no interior desse perímetro, o desenvolvimento de seu físico e de seu espírito será estimulado por todas as contribuições da psicopedagogia e controlado por uma vigilância discreta. No outro caso, o da família popular, Donzelot define o modelo pedagógico como o de liberdade vigiada. $\mathrm{O}$ que constitui um problema, no que diz respeito ao fato de que não é tanto o peso das pressões arcaicas, mas sim o excesso de liberdade, o abandono nas ruas, e as técnicas instauradas que consistem em limitar essa liberdade, em dirigir a criança para espaços de maior vigilância, como a escola ou a habitação familiar.

Pretende-se que a habitação se transforme numa peça complementar à escola no controle das crianças: que seus elementos móveis sejam banidos para que nela possa imobilizar as crianças. A busca da 
intimidade, a competência doméstica proposta à mulher popular, são o meio de fazer aceitar, de tornar atraente esse habitat que passa, de uma fórmula ligada à produção e à vida social, a uma concepção fundada na separação e na vigilância. Se o homem preferir o exterior, as luzes do cabaré, se as crianças preferirem a rua, seu espetáculo e suas promiscuidades, será culpa da esposa e da mãe (DONZELOT, 1986[1980]).

Segundo Donzelot, desde a década de 1840 até o final do século XIX, na Europa, as leis que editam normas protetoras da infância se multiplicam, como a lei sobre a insalubridade das moradias de 1850. Busca-se, através desses mecanismos disciplinares regulamentares, reduzir a taxa de natalidade e impedir o uso da força de trabalho infantil, tão importante e utilizada pela economia doméstica dos pobres urbanos. Contudo, é claro que, criar as leis não garante que elas sejam seguidas, e, fiscalizar seu cumprimento é muito difícil em cidades de grande porte. Assim, a proibição do trabalho infantil é complementada pela utilização do ensino obrigatório como estratégia biopolítica que não somente inibe os pais de se utilizarem da força de trabalho de seus filhos, como a torna imoral por atentar contra o futuro da criança e a sua possibilidade de ascensão social através da educação. Esse movimento de normalização da relação adulto-criança procurava não só corrigir a situação de abandono em que poderiam se encontrar as crianças da classe trabalhadora, mas também, por

$$
\begin{aligned}
& \text { "reduzir a capacidade sócio- } \\
& \text { política dessas camadas, } \\
& \text { rompendo vínculos iniciáticos } \\
& \text { adultos-criança, a transmissão } \\
& \text { autárquica dos saberes } \\
& \text { práticos, a liberdade de } \\
& \text { movimento e de agitação que } \\
& \text { resulta do afrouxamento de } \\
& \text { antigas coerções } \\
& \text { comunitárias." }
\end{aligned}
$$

(DONZELOT, 1986[1980], p.76).

De um lado, aparecem sociedades formadas pela iniciativa privada, para substituir o Estado, no que diz respeito à criação das crianças moralmente abandonadas, delinquentes, insubmissas à autoridade familiar. De outro, vê-se multiplicar as sociedades protetoras $\mathrm{da}$ infância, que tem como objetivo inserir nas famílias populares métodos modernos de criação e de educação das crianças. Essas atividades de assistência e repressão, antes tratadas separadamente, agora veem a família como um campo de intervenção direta. "Dupla linha, cuja conjunção anuncia 
o caráter de tutelarização social que revestirá a gigantesca campanha sanitária e moral das classes pobres, lançada no final do século XIX" (DONZELOT, 1986[1980], p.85).

Para impossibilitar a resistência do poder paterno, o Estado busca regulamentar a transferência de soberania da família "moralmente insuficiente" para o corpo dos notáveis filantropos, magistrados e médicos especializados - através da perda dos direitos de pais que, por embriaguês, maus procedimentos, maus tratos, comprometiam tanto a segurança quanto a saúde e a moralidade dos seus filhos - podendo ser confiada a guarda dos filhos, em casos de crimes cometidos por ou contra crianças, à Assistência Pública ou a uma pessoa ou sociedade caridosa. (DONZELOT, 1986[1980], p.81).

\footnotetext{
"Apoiando-se uma a outra, a norma estatal e a moralização filantrópica colocam a família diante da obrigação de reter e vigiar seus filhos se não quiser ser, ela própria, objeto de uma vigilância e de disciplinarização"

(DONZELOT, 1986[1980], p.81).
}

A família não faz mais parte do campo sócio-político, e, agora, a partir dela, pode-se estabelecer mecanismos de integração social. Para o referido autor, estes são resultados das intervenções que fazem funcionar a instância familiar. Nesse sentido, a família moderna é um mecanismo mais que uma instituição:

$$
\begin{aligned}
& \text { "Mecanismo maravilhoso, já } \\
& \text { que permite tanto responder } \\
& \text { à marginalidade com uma } \\
& \text { despossessão quase total dos } \\
& \text { direitos privados, quanto } \\
& \text { favorecer a integração } \\
& \text { positiva, a renúncia à questão } \\
& \text { do direito político por meio } \\
& \text { da busca privada do bem- } \\
& \text { estar. (DONZELOT, } \\
& \text { 1986[1980], p.89)" }
\end{aligned}
$$

\section{Contexto familiar brasileiro: Para além das "estratégias de sobrevivência"}

Cláudia Fonseca (1999) tenta comparar, de forma resumida, o modelo de transformação da família aplicado na Europa com o do Brasil e apresenta a forma familiar correspondente ao contexto social específico. Ao falar sobre a evolução da vida familiar entre grupos populares no Brasil, a autora apresenta um contexto social quase oposto ao caso Europeu: um Estado pobre desprovido de recursos para sustentar políticas sociais capazes de intervir com eficácia nas relações familiares da população 
-, uma população que vive em condições de vida precárias, e a descredibilidade ou ausência da escola.

Com a ausência de um sistema escolar eficaz e/ou acessível, as crianças continuaram se socializando pelo "trabalho infantil" e convivendo com adultos. Além disso, a família chefiada pela mulher chega a ser tão comum quanto a família conjugal: "juntavam-se sem casar, pariam filhos sem fazer certidão de nascimento e separavamse sem fazer divórcio." (Fonseca, 1999, 70).

Para Sylvia Leser de Mello (2003 [1995]), o que incita mais a discussão e reflexão sobre as questões da família, tem relação com "alguns inquietantes sintomas" de etnocentrismo ou do preconceito que se tem por algumas organizações familiares, especialmente, a da família das classes populares. Os hábitos e costumes das classes populares dificilmente são vistos como inseridos dentro de um contexto de diversidade cultural, salvo quando há raízes étnicas ou históricas. $\mathrm{Na}$ grande maioria das vezes, acabam por serem alvo de intervenções repreensivas ou de "recuperação". As diferenças que são admitidas e evidenciadas são vistas como degeneradas ou patológicas, falhas de "nossa" organização social, mas que na verdade representam a organização social das classes dominantes.
"Para falar de povos longínquos, agilizam-se conceitos tais como 'ritos agonísticos', 'sociabilidades tribais' e 'famílias consangüíneas'. Chegando perto de casa, estes são substituídos por termos tais como 'violência', 'promiscuidade' e 'famílias desestruturadas'.

Relativizar as práticas de pessoas que partilham de nosso universo é questionar nossos próprios valores; é admitir as contradições de um sistema econômico e político que cria subgrupos com interesses quase opostos. Nossa abordagem não deve ser confundida com um relativismo simplista. Procurar compreender certas dinâmicas não significa louválas, nem advogar sua preservação. Significa, antes, olhar de forma realista para as diferenças culturais que existem no seio da sociedade de classe - sejam elas de classe, gênero, etnia ou geração; significa explorar o terreno que separa um indivíduo do outro na esperança de criar vias mais 
eficazes de comunicação" (FONSECA, 2004[2000], p. 14 [grifos nossos]).

Cynthia Sarti (2009) discorre sobre a tradição das ciências sociais no Brasil trabalharem com "os pobres" predominantemente a partir de sua relação com o trabalho. Além desta, porém segundo a mesma lógica, as pesquisas sobre a família da classe trabalhadora serão pensadas não apenas como "reprodução da força de trabalho", mas também analisadas a partir das "estratégias de sobrevivência". Contudo, mesmo a perspectiva das estratégias de sobrevivência apresenta limitações e é preciso lançar outro olhar, para além das questões de privação, da pobreza na qual vivem.

O trabalho aqui presente traz como foco uma habitação coletiva muito peculiar: uma ocupação de sem-teto. Grande parte dos moradores vieram de outras cidades e estados em busca de melhores condições de trabalho e vida. Entretanto, apesar da relevância da condição social dos seus moradores, ela não pode explicar tudo. É preciso ver além da sua condição precária para compreender como se estabelecem as relações sociais. Não se trata de deslocar os moradores de seu contexto social, muito pelo contrário, trata-se de melhor compreender as práticas criativas dos atores que, apesar de condicionadas ao contexto, não são por ele determinadas.

$$
\begin{aligned}
& \text { "As análises centradas } \\
& \text { exclusivamente em relações } \\
& \text { de dominação, apesar de } \\
& \text { levantarem considerações } \\
& \text { fundamentais, podem ter um } \\
& \text { efeito inesperado. Ao reduzir } \\
& \text { o universo simbólico dos } \\
& \text { "subalternos" a um mero } \\
& \text { subproduto das normas } \\
& \text { dominantes, arriscam reforçar } \\
& \text { a violência simbólica que } \\
& \text { denunciam" (De Certeau, } \\
& 2008 \text { [1996], p.65). }
\end{aligned}
$$

\section{A ocupação Quilombo das Guerreiras e a tensão indivíduo-família-Coletivo}

Em 2006, após duas tentativas frustradas, um grupo de cerca de 50 famílias ocupou um imóvel da Companhia Docas, localizado na Avenida Francisco Bicalho, próximo à Rodoviária Novo Rio. O grupo era formado por pessoas pobres, exhabitantes de favelas e imigrantes vindos de outras regiões do país, carentes de moradia, e alguns ativistas universitários que, em sua maioria, reivindicava o anarquismo e compunha diferentes organizações 
associadas em uma frente: a Frente de Luta Popular (FLP). Entre 2004 e 2008, esta frente (rompida em 2008) ocupou quatro prédios na Zona Portuária e em todos eles organizou os moradores em Coletivos, que deveriam autogerir-se, ou seja, administrar o prédio e negociar a permanência através da realização de assembleias, onde cada família residente teria o direito a um voto. Neste sentido, o Coletivo foi instituído como uma estratégia política de organizações de "extrema esquerda", que buscava alavancar um processo mais amplo de transformação social. Contudo, tal processo não foi deflagrado e os Coletivos logo foram abolidos na prática, permanecendo apenas como um termo abstrato para designar o agregado de moradores de uma ocupação.

$$
\text { No entanto, na Ocupação }
$$

Quilombo das Guerreiras, o Coletivo foi ressignificado. Não adquiriu o caráter politicamente engajado em questões amplas de transformação da sociedade, como esperavam os ativistas de esquerda que participaram de sua formação, mas constituiu-se em uma representação grupal ou uma "imagem de nós"; tendo sido mantida a prática das assembleias semanais e as comissões de trabalho coletivo, como as comissões de elétrica, hidráulica, portaria, limpeza, finanças etc. No discurso dos moradores, em determinados momentos, o
Coletivo aparece designando as assembleias de moradores. Em outros momentos, o Coletivo é tratado como a ação em conjunto dos moradores, desde o momento da ocupação, até decisões punitivas àqueles que infringem as regras estabelecidas no Regimento Interno da ocupação. Deste modo, o Coletivo configura também uma instância normativa que estimula e sanciona comportamentos, julga infrações, e pune de acordo com as regras estabelecidas e de acordo com o caminhar das discussões nas assembleias.

O cumprimento das tarefas é registrado por listas de presença e as horas contabilizadas e expostas em reuniões de avaliação que ocorrem mensalmente. Portanto, viver no Coletivo significa ter que se submeter não apenas às regras do regimento, mas a um controle e vigilância constantes, além de ter que ratificar a sua adesão ao grupo através da participação em trabalhos comunitários e reuniões periódicas. Tais práticas fazem parte da construção de uma pedagogia de comportamento, de um controle das condutas, onde o "desvio" é reprimido segundo punições predeterminadas pelo regimento. No entanto, a rígida organização política da ocupação, fonte de inúmeras reclamações, é compensada, segundo os 
moradores, pela segurança e economia que ela proporciona. de dormir, a gente

dorme tranquilo. ${ }^{4}$

O controle e a vigilância são ainda intensificados pelas condições materiais do espaço físico da ocupação. $\mathrm{O}$ prédio abrigava o departamento de Engenharia da Companhia Docas e, portanto, é caracterizado por grandes salões e poucos banheiros por andar. A condição imposta pela Companhia Docas para a permanência dos moradores - que proibia a entrada de tijolos ou outros materiais que pudessem configurar moradia permanente - fez com que os moradores tivessem que construir as divisões dos amplos salões em unidades de moradia com tábuas e compensados de madeira, isto é, materiais pouco resistentes. Assim, além das obrigações acima mencionadas, os moradores reclamam da falta de privacidade devido às finas paredes que separam as habitações e a necessidade de compartilhar banheiros coletivos.

"Aqui a gente não tem
banheiro dentro de casa. A
gente não pode fechar a
nossa porta e parar de escutar
o barulho dos vizinhos. Não
é reservado. A conversa que
eu to tendo com você quem
passa ali fora vai escutar. A
gente não fica à vontade. As
tábuas [paredes] são de ESPAÇO E CULTURA, UERJ, RJ, N. 34, P.83-122, JUL./DEZ. DE 2013 http://www.e-publicacoes.uerj.br/index.php/espacoecultura/ 
madeira As crianças dormem aqui na sala. Não tem como fazer quarto aqui. Se fosse da gente, a gente até caprichava, né? Mas não é da gente. Estamos aqui de reserva, entendeu? Se fosse da gente podia até fazer uma coisa melhor. Aí vai gastar aqui, sem ter, vai tirar do pouco para colocar aqui e não vai compensar. Hoje ou amanhã você pode estar fora. Não tem como." ${ }^{5}$

O Coletivo configura um substantivo próprio que encarna a autorrepresentação coletiva dos moradores. Os conflitos e ameaças externas (como o perigo de despejo) aparecem como agentes unificadores do grupo. Por um lado, há uma tendência de se minimizar diferenças internas para que um grupo social mantenha a coesão entre os diferentes membros, e, por outro, para que se oponha aos demais grupos sociais, afirmando perante eles a sua unicidade (SIMMEL, 1964).

Entretanto, o estabelecimento do Coletivo como uma identidade coletiva faz emergir uma tensão, que se estabelece nesta forma de sociabilidade, marcada pela relação entre o Coletivo e a família. A relação indivíduo-Coletivo é frequentemente permeada pela família, o que permite pensar em uma relação "indivíduo-famíliaColetivo" (ou pelo menos arranjos familiares). Vemos, nesse caso, uma tensão que não é comum a outros movimentos sociais. Quando se trata de uma mobilização animada pelo espaço-tempo do trabalho, por exemplo, o indivíduo coloca-se em sua própria condição de indivíduo vinculado a uma coletividade definida por sua classe social. No entanto, a questão da habitação percorre as relações familiares e, em certos momentos, tal dimensão torna-se moralmente importante - uma vez que o "chamado moral" do vínculo estabelecido com a família muitas vezes tende a se sobrepor àquele incitado por um Coletivo com o qual se tem menos convívio ou este é rarefeito e instável. Essa tensão merece ser aprofundada, considerando, inclusive, as facilidades e dificuldades que envolvem o processo de criação de filhos em meio a um ambiente onde também o Coletivo está presente - uma vez que se trata de uma instituição que não existia antes, quando a própria experiência de "ter" uma família foi iniciada.

\section{A coletivização do cuidado com as crianças: o "jogo" entre Coletivo e Família}


A família não deve ser mais

apenas uma teia de relações

que se inscreve em um

estatuto social, em um

sistema de parentesco, em

um mecanismo de

transmissão de bens. Deve-se

tornar um meio físico denso

saturado, permanente

continuo, que envolva,

mantenha e favoreça o corpo

da criança. (...) o que acarreta

também uma certa inversão

de eixo: o laço conjugal não

serve mais apenas (nem

mesmo talvez em primeiro

lugar) para estabelecer a

junção entre duas

ascendências, mas para

organizar o que servirá de

matriz para o indivíduo

adulto' (DUARTE, 1979, p.

199)"

Apesar das crianças e adolescentes não poderem participar das assembleias, eles eram, sem sobra de dúvida, um dos temas mais debatidos pelos moradores. $\mathrm{Na}$ medida em que as crianças foram ficando mais velhas e "arteiras", os pais começaram a ser responsabilizados pelas atitudes de seus filhos. Se um dos filhos escangalhasse, quebrasse ou roubasse algo, os pais pagariam. O Coletivo entendia que, uma vez que os pais começassem a arcar com as consequências dos atos de seus filhos, não só financeiramente, mas com advertências na assembleia também, tomariam maior cuidado com seus filhos, teriam uma maior preocupação em vigiá-los. A preocupação com a vigilância do cuidar tornou-se tão presente, que algumas mães trancavam seus filhos dentro de casa quando iam trabalhar, esperando que assim pudessem os proteger e evitar problemas com os vizinhos. Entretanto, essa atitude foi muito questionada por outros moradores, ao ponto do Conselho Tutelar ter sido chamado, anonimamente, através de uma denúncia do suposto cárcere. $\mathrm{O}$ caso, posteriormente, passou a ser utilizado para pressionar os pais (especialmente as mães) a cumprir sua responsabilidade sobre os cuidado dos filhos. Sempre que o comportamento das mães não condizia com as expectativas do Coletivo, alguém ameaçava chamar o Conselho Tutelar.

Assim, vemos que, mesmo quando a ação normalizadora não ocorre diretamente por meio de instituições vinculadas ao Estado, elas ainda assim podem ser usadas por outros agentes para induzir uma mudança de conduta. As exigências externas, mesmo quando partem de uma coletividade, de um amigo ou do interior da família, são coerentes com normas estatais e 
normas morais (compreendidas como mediações discursivas que permitem que uma série de mecanismos incida sobre o comportamento social), visto que reforçam a obrigação de reter e vigiar seus filhos, se a família não quiser ser, ela própria, objeto de uma vigilância e de disciplinarização.

\section{Uma nova tática para cercear a territorialidade das crianças}

Com as reclamações em relação às crianças se tornando cada vez mais frequentes nas assembleias, na segunda metade de 2010, foi decidido que as crianças só poderiam brincar em seus andares. Elas poderiam dispor dos corredores de seus andares e também da sala das crianças - o chamado "Salão Preto" que é o espaço destinado para as festas e também utilizado como quadra para crianças desde o início da ocupação - para este fim. No final do mesmo ano, decidiram fechar o acesso das crianças também ao pátio externo (que fica no terceiro andar deste prédio) até que se construísse uma grade de segurança no mesmo, para evitar que crianças pequenas não supervisionadas viessem a sofrer um acidente. Porém, para isso, tiveram que fechar também o salão das crianças, destinando outra sala para suas brincadeiras (mesma sala que funciona as assembleias). O mais interessante, contudo, é que a proposta de encaminhamento para limitar a mobilidade das crianças na ocupação foi feita por uma mãe solteira, que trabalha fora e que vê, constantemente, o nome dos seus filhos envolvidos em polêmicas na assembleia. Ela recorre ao Coletivo, para que este a dê suporte para a organização das relações de poder dentro do território doméstico.

"Eu acho que as crianças agora estão bem mais calmas, não acha? Eu acho. Antes você não conseguia parar para conversar com uma criança, elas eram muito agitadas. Quem propôs esse negocio fui eu. Cheguei na assembleia e falei: 'cada criança no seu andar'. Se eu pudesse meus filhos não saiam de dentro de casa. Porque é uma forma de não ter problema lá fora. $\mathrm{A}$ partir daqui [da porta] eu não mando, só mando aqui dentro. Se eles quebrarem alguma coisa por aqui eu compro [outro] a hora que eu quiser, é minha, tá paga. Agora se eles quebram um banco lá fora, já vai problema pra reunião, entendeu? Se eles fizerem coisas lá fora, eu que vou ser chamada na 
reunião, eu que vou ter que pagar." 6

Assim, as mães evocam o Coletivo para que sancionem regras que, geralmente, remetem ao território doméstico, como a definição de por onde seus filhos podem transitar. Ao transformar uma regra doméstica em uma regra coletiva, elas reforçam sua autoridade sobre seus filhos e, ao menos momentaneamente, estendem as fronteiras do território doméstico para toda a ocupação. Aquilo que, a primeira vista, parece uma interferência do Coletivo na vida privada dos moradores é, na verdade, um recurso de legitimação da hierarquia doméstica. Além disso, a proposta da referida moradora tornou todos os moradores coresponsáveis pelo cuidado e a vigilância dos seus filhos. Quando o Coletivo delibera que os pais serão responsabilizados pelas atitudes das crianças, ele o faz visando estimular uma maior vigilância dos pais sobre seus filhos. Por outro lado, tal deliberação serve, também, para ratificar e consolidar essa relação hierárquica no lar, visto que torna explícito para a criança quem é responsável por elas. Se um adulto vir as crianças brincando em andares que não os delas, ele tem a legitimidade e a obrigação para mandá-las de volta às suas casas.

\section{A resistência à territorialidade} imposta e as redes de conexidade das crianças

Até esse momento, as crianças foram tratadas somente como agentes passivos nesse "jogo" entre a família e o Coletivo. No, entanto, longe de aceitar passivamente as limitações impostas pelo Coletivo à sua mobilidade, as crianças desenvolvem suas próprias táticas de transgressão. Com isso elas também exercem um protagonismo dentro da ocupação. Elas subvertem a territorialidade imposta, e constroem sua própria territorialidade, assim como constituem novos vínculos familiares.

Em sua análise sobre a relação entre as famílias e as redes sociais, Elizabeth Bott (1976 [1971]) discute o impacto da localidade no estabelecimento do que chama de "redes de conexidade". Para autora, compreender como as relações familiares atuam implicaria focalizar não apenas relações mais estreitas, mas também, a "parte da rede composta pelos vizinhos", bem como pelas "redes independentes do marido e da esposa" e o modo como se dá a "conexidade dessas redes com a rede total" (BOTT1976 [1971, p.76).

Apesar da autora se ater às conexões estabelecidas pelos maridos e suas 
respectivas esposas, podemos ver, de forma bastante clara, como as redes tecidas pelas mães, pais ou outros membros da família não são, necessariamente, as mesmas que os filhos estabelecem. As redes são produzidas de formas diversas. Às vezes elas percorrem vínculos sanguíneos e, portanto, se encontram indexadas a relações que precedem o indivíduo que nela está inserido (mesmo que isso não assegure a continuidade do vínculo ao longo da vida). Contudo, as redes familiares também são construídas por meio de relações que produzem tudo aquilo que no caso da consanguinidade é tomado como certo. Mesmo assim, geralmente, as crianças não são produtoras de suas próprias redes de cuidado. Pelo contrário, encontram-se já posicionadas nas redes tecidas por seus pais. Qualquer eventual rompimento da relação entre os pais de uma criança e uma determinada pessoa adulta resulta, também, no mesmo efeito para os seus filhos. Entretanto, na ocupação estudada, as "redes de conexidade" também são tecidas pelas crianças que, apesar destas encontrarem sua limitação nas fronteiras do território da ocupação, traçam linhas de conexão que independem de seus pais, respaldadas pela corresponsabilização coletiva do seu cuidado.
Assim, pretendo refletir sobre o estabelecimento das "redes de conexidade" no que concerne o papel ativo das crianças neste processo. Em relação a não passividade da criança em seu processo de socialização, Christina Toren (1999) argumenta que o indivíduo não é um agente passivo que recebe os significados prontos. A crítica da autora é no sentido de questionar a ideia de as crianças serem passivas em relação ao seu mundo social. Ou seja, as crianças não sofrem apenas a socialização, elas também socializam a si próprias. Não são apenas os cuidadores que engajam as crianças nas relações, as crianças também engajam seus cuidadores. A criança passa a ser, nessa visão, um sujeito ativo.

Marília é um exemplo ilustrativo. Ela tem apenas cinco anos de idade e é a terceira de um total de 5 irmãos. Seus pais trabalham o dia inteiro e a deixam sob os cuidados de sua irmã mais velha, Mara, de 13 anos de idade. Mara é responsável por uma série de tarefas domésticas, além de cuidar de seus 4 irmãos mais novos. Contudo, Marília, desde os 3, aprendeu a se virar sozinha, e Mauro (seu irmão), hoje com três anos de idade, já segue os passos de sua irmã. Ambos andam sozinhos por todo o prédio a procura de diversão, comida e carinho. Uma vez estava esperando o início de uma reunião, quando avistei 
Marília subindo as escadas, exibindo seu sorriso carismático. Quando ela me viu, veio correndo na minha direção. Peguei-a no colo e perguntei como estava. Marília me respondeu: "Tô com sede, quero água." Prontamente, levei-a até a cozinha coletiva e lhe ofereci um copo d'água. Saciada, Marília devolveu o copo, já sorrindo novamente, e foi embora. Posteriormente, vi Marília utilizar a mesma técnica para pedir colo, carinho, comida e até banho. Comecei a me interessar mais e mais pelos hábitos dessa pequena criança e, aos poucos, percebi que Marília já havia constituído, por si mesma, sua rede de cuidado. Contabilizei quatro moradores que recebiam Marília com frequência em suas casas para ver televisão, brincar de boneca ou mesmo para tirar um cochilo. Uma das moradoras, com filhos já crescidos, chegava até a guardar roupas de criança para vesti-la depois do banho. Com o tempo, percebi que outras crianças também se aproximavam de adultos, independentemente de seus pais, para ir à praia, tomar sorvete, passear, fazer o dever de casa etc. Adelaide, moradora da ocupação e mãe de Marília, deixa isso claro:

\footnotetext{
"Aqui quando tem alguém precisando, todo mundo chega junto, todo mundo ajuda. Aqui é tipo uma
}

família. Por exemplo, se eu estiver doente, minha vizinha vai na minha casa, oferecer uma roupa para lavar, me leva no hospital se precisar, faz uma comida para mim. Aqui a gente é tipo uma família, entendeu? Ninguém deixa de dividir nada. Mesmo aquelas pessoas que não tem muita afinidade, precisou, todo mundo ajuda. Eu saio pra trabalhar, e eles me ajudam bastante. Olham as crianças pra mim, todo mundo junto. Ajuda, todos eles. [...] Facilita muito! Para a gente ir trabalhar é a melhor coisa que tem. Porque você vai trabalhar e sabe que seu filho tá tranquilo, não vai para rua, sempre tem um pessoa aqui na portaria pra olhar, não deixar sair."${ }^{17}$

Neste sentido, as crianças também territorializam a ocupação ao seu modo. Não raro, a rede tecida pelas crianças não recebe a aprovação de seus pais que os proíbem de frequentar a casa de moradores com os quais não possuem uma relação fraterna, contudo impedir a continuidade de tais vínculos. Muitas vezes pude presenciar 
genuínas relações de carinho e afeto estabelecidas entre crianças e adultos na ocupação, sendo que este adulto "não se dava" com a mãe da criança. Deslumbrei-me ao ver crianças de três, quatro anos que, uma vez percebida a disponibilidade do adulto em se preocupar com o bem-estar das mesmas, acionavam aqueles quando precisavam ou buscavam carinho, alimentação ou passar o tempo. Da mesma forma, vejo as crianças mais velhas, os adolescentes, carregando compras e fazendo visitas periódicas aos adultos com os quais eles possuem uma maior afinidade, sem que isso tenha algo a ver com a relação destes com seus pais. Aliás, muitas vezes, eles sequer estão cientes disso.

"Meus filhos brincam [na casa dos outros]. Eu vou dizer que não brincam? Ia estar mentindo. Quem vai segurar criança? Ninguém segura. Ninguém segura criança, não. Ninguém pode com criança. Quem inventou isso foi a Patrícia: 'Não quero meus filhos em andar nenhum'. Vai ver os filhos dela? Não saem daqui de casa, andam pelo prédio todo. Não adianta nada $^{1 / 8}$

\section{A casa e as condições materiais da} intimidade

A segmentarização do espaço urbano - na construção daquilo que Foucault denominou de "espaço disciplinar" (FOUCAULT, 2007 [1975]) - atravessou as fronteiras do privado e promoveu, como vimos, a subdivisão do espaço doméstico. Assim, ao mesmo tempo em que o espaço privado se diferencia do espaço público, o espaço privado se subdivide internamente para abrigar novos costumes, comportamentos e práticas que demandam um espaço próprio para o indivíduo, separado do restante da família.

A transformação das relações de poder na sociedade (com a ascensão da burguesia) incide, também, nas relações familiares, produzindo desejos intimamente ligados à privacidade. Assim, dentro do espaço doméstico, território da família, o indivíduo busca um espaço seu e demarca um território ainda mais privado, que delimita uma fronteira clara entre aquele que dele se apossa e nele guarda seus segredos, e aqueles cujo acesso é impedido. Utilizo aqui uma expressão ensaiada por Safarty-Garzon, em seu livro, territoires de l'intimité (traduzido aqui como território íntimo ${ }^{9}$ ), para argumentar que esse é fruto da transformação das relações de poder do espaço doméstico, e que foram 
apresentadas ao longo deste capítulo, inspiradas nas transformações que dizem respeito à revalorização da família.

De todo o modo, o território demarca uma fronteira no espaço que institui um dentro e um fora, e seleciona e condiciona o acesso $^{10}$. Vimos que as transformações das relações de poder na sociedade fizeram surgir novas territorialidades que modificaram, inclusive, o espaço doméstico. A vinculação da mulher com o lar - e sua responsabilidade para fazer deste uma expressão do status e da personalidade da família -, ao mesmo tempo em que aprofunda a fronteira entre o espaço público e o espaço privado, também requer algo que se torna cada vez mais importante com o crescimento e a aceleração do processo de urbanização: a diferença.

"[P]ara salvar o que há de mais pessoal é preciso convocar o que há de extremo em peculiaridade e particularização, e é preciso exagera-las para que se possa tornar audível, inclusive para si mesmo" (SIMMEL, 2005[1903], p. 588).

Portanto, para diferenciar-se dos demais, para se individualizar e expressar sua personalidade, não é suficiente demarcar fronteiras; é preciso dar ao território qualidades únicas, particulares, capazes de distingui-lo dos demais; em outras palavras, é preciso dar-lhe uma identidade própria. Assim, o espaço doméstico - ao constituirse cada vez mais como território doméstico - demanda a configuração de conjuntos de símbolos particulares que expressem não só o status, mas também, a personalidade da família. Da mesma maneira, o "território íntimo" não prescinde de significações que expressem características particulares da personalidade individual. Neste sentido, a dimensão afetiva ganha relevância, o que nos obriga a refletir sobre o "território íntimo", também, como "lugar".

O "lugar" confere qualidade ao território, produz, sob uma constelação de poderes, significados e símbolos próprios, que retiram do mundo aquilo que desejam nutrir em si mesmo, sem que, necessariamente, isso implique em simples repetição. O "lugar" cria enunciados, que atravessam e modificam as relações de poder, mas não se restringe a elas. Deste modo, é claro que o "território íntimo" é vivenciado e significado por quem dele se apropria, sendo possível, também, compreende-lo como um "lugar" que remete à expressão pessoal e particular da identidade do indivíduo, e como este projeta tais significações no espaço social. 
As ocupações aqui mencionadas, assim como as habitações coletivas de forma geral, costumam ser referenciadas em oposição à casa burguesa, que aparece como o modelo ideal doméstico. Tais habitações são consideradas exemplos de "incivilidade", e promiscuidade: "sujas", "fedorentas" e "desconfortáveis", por serem muito pequenas e com pouca iluminação; sem intimidade ou individualidade, pois são casas densamente habitadas, pouco ou nada segmentadas, sem funções únicas e com banheiros coletivos. Além disso, comportamentos pouco discretos são atribuídos aos seus moradores, como a gritaria, por briga ou conversa, o fato de viverem nas casas uns dos outros ou nos corredores, no pátio e na portaria, fofocando sobre a vida alheia. Por isso, seria quase impossível isolar o indivíduo do controle coletivo, pois não haveria, por parte deles, o desejo da "solidão". Devido a representações como essas, as habitações coletivas populares foram sendo encaradas como a manifestação contemporânea de um modo "atrasado" e "degenerado" de habitar. Ao mesmo tempo em que ela estabelece como positividade, como meta, como objetivo, a instauração de um espaço doméstico ideal burguês, essa reformulação das relações nos espaços domésticos é absorvida, em parte, pelas classes populares.
As condições materiais neste caso são extremamente importantes, pois dificultam a adoção de uma vida familiar burguesa. Faz-se mister ressaltar que falo aqui da condição específica dos sem-teto. A situação de sem-teto leva a uma vida marcada pela habitação de caráter provisório e precário, tendo que arcar com os custos do aluguel, em casas de cômodos ou em cortiços, até em abrigos ou mesmo na rua.

Neste sentido, o acesso ao trabalho se configura como uma questão central para essas famílias. Seus parcos recursos materiais levam à necessidade de contar com a ajuda dos filhos mais velhos, seja nas tarefas domésticas, ou trazendo dinheiro para casa, normalmente através de "bicos" , que não só limita o tempo de convívio com os outros membros da família, mas também, incide diretamente nas relações de poder familiares, fazendo com que filhos ou filhas mais velhas, que já assumem tarefas de adultos, se imponham como tal na hierarquia familiar.

Entretanto, é necessário enfatizar que as práticas dos sem-teto não são meras reproduções determinadas por esses condicionamentos materiais. É preciso enxergá-los para além de consumidores passivos. Segundo Michel de Certeau, seria então, necessário analisar a sua manipulação 
por parte desses usuários, observar a criatividade das práticas humanas comuns da vida cotidiana no campo do consumo. Sem negar a influência da cultura hegemônica, De Certeau nos lembra que "existem dinâmicas culturais, nascidas no sens pratique da vida cotidiana, dignas de estudo". Essas "formas sub-reptícias que são assumidas pela criatividade dispersa, tática e bricoladora dos grupos ou dos indivíduos presos agora nas redes de vigilância" (DE CERTEAU, 2008 [1996], p.41).

Neste sentido, existe uma multiplicidade de formas de apropriação do espaço, tanto como território quanto como "lugar", apesar de geralmente o espaço familiar ser caracterizado por poucos símbolos que denotam a personalidade da família. Em outras palavras, o que pretendo descortinar são as lógicas e regras destes modos de habitar, que, para nós, parecem tão caóticos. São formas de interação que vão se formando ao longo do tempo, por essas práticas da vida cotidiana.

Uma primeira observação diz respeito às disputas e confrontos territoriais referentes aos espaços domésticos que, apesar de não serem característicos apenas das habitações das classes populares, são acirrados devido ao tamanho da moradia e ao adensamento familiar, às condições do substrato material 11 e à precariedade das habitações (dificuldade de conseguir recursos básicos como água, eletricidade, ou gás). Além disso, o fato das mulheres passarem pouco tempo em casa, por causa do trabalho, faz com que crianças e adolescentes, meninos ou meninas, terminem por assumir tarefas que caberiam aos pais ou empregados numa casa burguesa. A instabilidade da moradia também constitui um fator gerador de conflitos intrafamiliares. Essa necessidade de deslocamento frequente se reflete no caráter provisório de sua moradia, na dificuldade de estabelecer-se, o que dificulta a acumulação de bens materiais. Assim, elas recomeçam a cada vez que partem em busca de um novo lar e uma nova vida.

Algumas práticas espaciais podem ser vislumbradas a partir das observações feitas acima. Em primeiro lugar, o desejo de conquistar um "território íntimo", mesmo com as limitações impostas pela pobreza, está presente tanto nas falas, quanto nas estratégias espaciais adotadas pelas moradoras. Há, quase sempre, no âmbito das famílias compostas por mãe e filhos, uma tentativa de impor a demarcação de um "território íntimo", algumas vezes sem sucesso, pois tal espaço, apesar de existir materialmente, é também reivindicado pelos outros integrantes da família. Quando a 
territorialização da intimidade revela-se impossível, busca-se uma alternativa, como, por exemplo, a constituição de um "território íntimo" fora de casa, como no caso das mães solteiras que possuem namorado.

Além disso, podemos observar, também, a constituição do território doméstico enquanto "lugar". O pouco tempo em que as mulheres passam em casa, a falta de dinheiro para investir em melhoramentos, a falta de uma garantia em relação à regularização do imóvel, ou mesmo o fato de possuírem outros interesses, surgem como condicionantes neste processo de "lugarização" do espaço. Mesmo assim, os símbolos referentes à história de vida dos moradores e às suas preferências, manifestam-se através de marcas espaciais discretas, que revelam um pouco da personalidade de cada um, como cortinas escondendo as paredes de madeira, as imagens estampadas nas paredes, e a reutilização de materiais recicláveis, assim como os objetos que utilizam como referenciais, para incrementar as habitações. Assim, as marcas do "lugar" das habitações dos sem-teto, diferentemente das casas burguesas, são muito mais sutis do que as suntuosas cortinas de seda, o lindo piano Fazioli, ou o tapete Persa da sala de estar, contudo, nem por isso são menos expressivas.

\section{Mulheres vivendo sozinhas: $O$ espaço doméstico como expressão da identidade}

Ao pensar sobre a situação das mulheres solteiras poderiamos pressupor que não houvesse necessidade de separação dos espaços domésticos, uma vez que todo o espaço domiciliar seria seu território. Entretanto trago um exemplo que nos faz repensar essa construção a priori do que seriam as causas primordiais para $\mathrm{O}$ estabelecimento de espaços mais reservados.

O exemplo que acho interessante apresentar é o de Laura. Laura não apenas é uma das lideranças da ocupação, como esteve presente como apoiadora e moradora em outros processos. Ela se destaca pelo afinco com o qual se dedica às tarefas internas à ocupação, à crença na "força do Coletivo", na horizontalidade das relações de poder e na autogestão, aliada à determinação e o incansável esforço de construção do seu sonho. Para ela, o processo de construção e convencimento, para essa forma coletiva de viver, demanda um engajamento cotidiano e um processo contínuo de convencer e convencer-se da 
importância da construção coletiva: "Um convencimento diário", diz ela.

$$
\text { Por Laura ser tão engajada }
$$

politicamente, seu espaço de moradia, não raro, é utilizado para as reuniões com apoiadores e é bastante frequentado por outros moradores buscando algum tipo de informação ou querendo resolver algum problema. Assim, seu espaço de moradia acaba adquirindo contornos mais "públicos". Laura já teve problemas por essa associação de seu espaço de moradia como extensão do espaço coletivo. A dificuldade de entender essa delimitação é, segundo ela, maior para os apoiadores da ocupação. Contudo, Laura não abre mão de delimitar suas fronteiras. Mesmo de porta aberta, ela pede para que batam na porta antes de entrar. A partir da experiência por ela relatada, podemos ver como ela é apegada ao seu lar e como exige que os "de fora" respeitem seu território, seja quem for. É uma estratégia utilizada para estabelecer quem são os insiders e os outsiders e que condiciona as relações sociais e controla o acesso.

"Minha casa é realmente uma casa aberta. Aberta para as pessoas, é claro, que eu tenho mais afinidade. Tive problemas com isso porque as pessoas de fora acham que nossa casa ainda é um espaço coletivo... Digo minha casa, não no sentido de ser meu, mas acho que é muito a minha 'cara', meu particular, ne'? É um quadro, é uma foto minha com minha mãe, uma coisa que sei lá, de repente você se sente bem sabendo que as pessoas que estão vendo aquilo tem um relação com você, né. Aí, de repente, você está dentro de casa vem uma pessoa que você nunca viu na vida, com um amigo seu? Uma vez eu tive um problema com um amigo, que era meu amigo pessoal. Um cara que eu amo pra caramba. E foi muito delicado ter que falar isso [com ele]. Entender que ele era ele, mas, cara, me senti agredida, né? Eu tava de costas, no fogão, fazendo café, quando eu virei, uma pessoa que eu não conheço. Eu acho que isso é ruim. Mas, de resto, gosto de fazer reunião [em casa], as crianças vem..."

Laura aponta a situação das crianças como outro exemplo relacionado ao mesmo problema. As crianças da ocupação não 
compreendiam que apesar de sua casa ser mais acessível, ainda assim, era preciso o seu consentimento para entrar em seu quarto. Laura descreve esse aprendizado como um "processo pedagógico" em que eles passam a entender que sempre poderão contar com ela e poderão recorrer a ela, porém, para isso, precisam respeitar os limites por ela exigidos. As fronteiras não precisam, necessariamente, ser fixas, ou mesmo concretas. Laura deixa isso claro ao falar de sua porta "sempre aberta".

"Com as crianças eu faço essa exigência, de bater, chamar na porta, né? Porque criança é criança, ela vai entrando, ela vai... E como eu moro sozinha e a gente não tem esse hábito de entrar na casa um do outro, às vezes eu to nua em casa. Minha porta tá aberta, mas ninguém entra na minha casa direto, e você não vai contar com uma criança. Às vezes. Meu espaço é aqui [aponta para o 'quarto'], mas às vezes eu deixei minha calça aqui em cima, no sofá, que eu vou vestir, venho de calcinha pegar, aí uma criança, entra? E assim, eu não tenho esse constrangimento, esse pudor, mas às vezes a criança tá com pudor, né? E não é uma coisa legal. Então, eu incentivo a bater na porta. E quando vou na casa deles eu bato na porta também. Eu chamo do corredor, pra eles perceberem que quando eu vou na casa deles eu chamo também antes de entrar. Mas então é assim. Eu acho que as pessoas que moram sozinhas ou até casais, não precisam fechar suas portas para ter privacidade. Porta, mesmo que ela esteja aberta, não é para entrar, né?"

Porém ela nunca teve esse problema com seus vizinhos. Ela aponta como para os moradores essa compreensão dos limites do espaço privado é importante. Eles sempre respeitaram seu espaço. A porta podia estar aberta que ninguém entra sem bater. Militante convicta e dedicada que é, não abre mão desta postura "disciplinada" no trato com os vizinhos e crianças.

Laura possui um dos quartos mais bem demarcados da ocupação, como podemos ver no croqui (figura 1). Seu quarto que, neste caso, é também seu território íntimo, está posicionado no canto direito, com um armário que impede a visão da cama quando se está na "sala de estar". Ela mesma ressalta que costuma trocar de ESPACO E CULTURA, UERJ, RJ, N. 34, P.83-122, JUL./DEZ. DE 2013 http://www.e-publicacoes.uerj.br/index.php/espacoecultura/ 
roupa ali, onde é mais escondido. Assim, ela oculta seu quarto do campo de visão de quem entra em sua casa, assegurando a sua privacidade.

Entretanto, para diferenciar-se dos demais, para se individualizar e expressar sua personalidade, não é suficiente demarcar fronteiras; é preciso dar ao território qualidades únicas, particulares, capazes de distingui-lo dos demais; em outras palavras, é preciso dar-lhe uma identidade própria.

Há uma densidade de símbolos encontrados em sua casa que a identificam: pôsteres de militância, esculturas feitas por ela, fotos de família e das crianças, entre outras. Não é só a existência de objetos ricos em significado, mas a posição de destaque destes que declara, para si e para os outros, um pouco de como ela vê a si mesma. Laura aprofunda sua territorialização, atribuindo significado ao espaço; esta é a forma mais clara de expressar a apropriação singular que ela faz do território.

CROQUI DOS ESPAÇOS PRIVADOS

Exemplo 1

(2011)

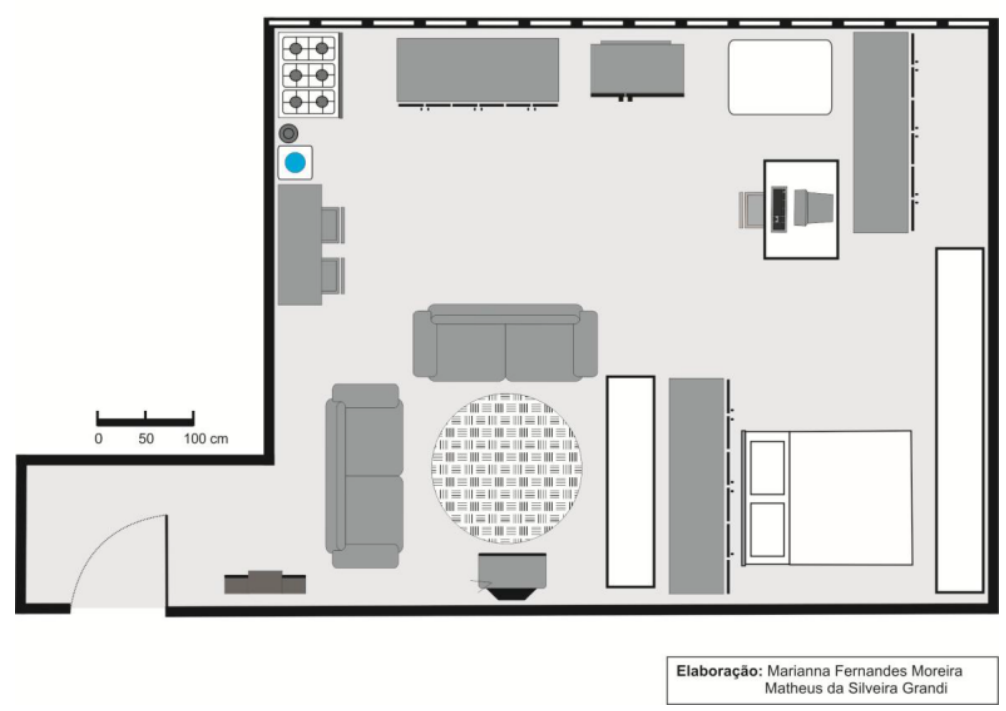

Figura 1.

Outro exemplo seria o caso de Bia.

Bia é uma mulher de 39 anos, solteira, e moradora da ocupação. Até quase completar trinta anos, Bia morava em Curitiba, com sua mãe e seu pai. Há dez anos, Bia resolveu vir morar no Estado do Rio de Janeiro, mais especificamente na cidade de Mangaratiba, para trabalhar com seu tio em barco de pesca. Durante quase dois anos ficou trabalhando com seu tio. Porém, devido ao esforço físico exigido neste tipo de serviço, seu tio resolveu "largar o emprego", deixando para Bia uma 
única opção: vir para a cidade do Rio de Janeiro.

Entrei poucas vezes na casa da Bia. Porém, sempre que entro, a recepção dela é a mesma: "Fique à vontade. Sente onde quiser". O seu território íntimo é todo o espaço doméstico. Uma vez ultrapassada esta fronteira, não há mais nenhum outro espaço mais reservado. Não existe em sua casa uma hierarquia dos espaços, uma especificação de funções (ver figura 2). Dona de cabelos curtos, roupas e atitudes masculinas, Bia veio para o Rio de Janeiro para se afastar do preconceito de seus familiares para com sua sexualidade, e para que, finalmente, pudesse viver a sua vida como quisesse.

Sua casa é muito simples, com poucos objetos, quase nenhuma decoração, porém "jeitosa"; tudo está no lugar. Até a geladeira sem porta, deitada no chão, imitando um aparador, combina com a casa. O sofá compõe o ambiente com a sua cama, em frente à televisão. O que mais chama a atenção na casa de Bia é, sem dúvida, os pôsteres de mulheres nuas ao lado da televisão. Lembro-me da primeira vez em que entrei no quarto dela. A sensação não era de incômodo por causa das fotos em si, mas porque me senti invadindo um espaço tão íntimo, que continham detalhes de sua personalidade/intimidade de maneira explícita. Não me senti incomodada, sentime incomodando, invadindo sua privacidade, pois não a conhecia tão bem quanto as demais entrevistadas.

Num contexto de pobreza e instabilidade, os detalhes caracterizam o "lugar" e exprimem características particulares de cada morador. Assim como Laura, que declara sua militância nas paredes, Bia declara sua homossexualidade. Porém, sua postura mais reservada não impõe uma necessidade de segmentar seu espaço doméstico em busca de privacidade.

“Eu não sou de ir na casa de ninguém. Também não sou de receber muita gente também, não. Não sou muito de frequentar a casa de ninguém, não. É próprio de mim. Sou mais reservada. Eu gosto muito de sossego. Eu gosto de paz. Eu não sou uma pessoa preguiçosa, eu gosto de sossego. Gosto de trabalhar, fazer minhas coisinhas, mas depois ter sossego, paz. Coisas muito avarentas assim eu já não gosto. Por isso que eu gosto da luz onde ela tá. Porque não fica na minha cara. Para ver televisão assim é bem melhor. Porque também eu não durmo de luz apagada. 


\section{CROQUI DOS ESPAÇOS PRIVADOS \\ Exemplo 5}

(2011)

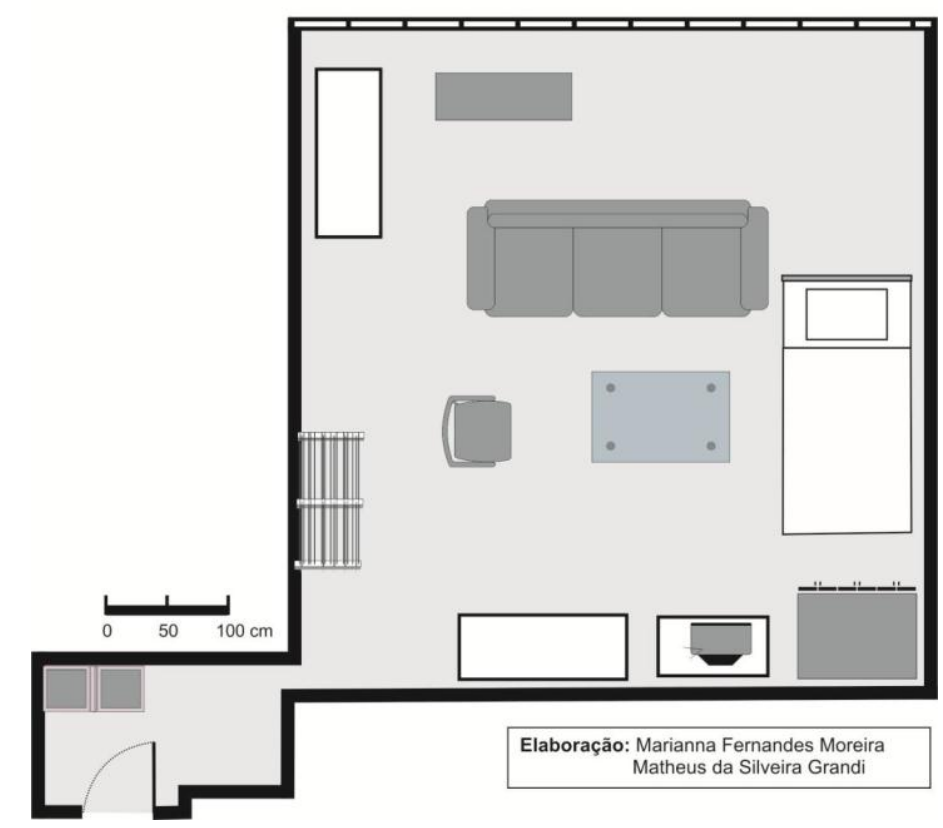

Figura 2

2. Mães solteiras: $\mathrm{O}$ território doméstico em disputa

O segundo caso que gostaria de tratar são os das mulheres com filhos. Nesse caso, as mães vão ter que tentar impor sua vontade de em determinados momentos preservar-se. Isso acaba por gerar uma negociação continua com seus filhos em busca de um território intimo. O primeiro exemplo é o de Patrícia.

Patrícia é paraibana, tem 41 anos de idade e sete filhos. No momento, apenas três moram com ela, Rafael, de treze, Paola, de doze, e Romário, de nove. Os filhos que moram na ocupação frequentam bastante os espaços coletivos. Sempre que estou lá, os vejo pelos andares. São crianças alegres, comunicativas e muito carinhosas.

Muitos moradores da ocupação circularam por muitos estados e cidades do Brasil à procura de estabilidade para assentar sua residência com melhores condições de vida. Patrícia, por exemplo, há vinte e um anos que alterna entre a Paraíba e o Rio de Janeiro como local de moradia. Quando a "coisa aperta" por aqui, ela vai para lá, próximo dos parentes, e vice e versa.

Patrícia trabalha como camelô e, digase de passagem, gosta bastante de seu 
trabalho. Ela fala que não sabe "viver de outra coisa". Muito envergonhada com a aparência de sua casa, mostra claramente uma aversão às tarefas domésticas:

"Meu sonho é colocar um barzinho. Porque eu adoro comércio. Não tenho jeito para outra coisa. Tanto que você vê, olha minha casa como é que é! Eu não tenho jeito. Eu não nasci para isso. Se fosse para viver de trabalhar em casa de família acho que eu morro de fome. Agora, se botar qualquer coisa pra vender eu vendo. Qualquer coisa"

Patrícia não consegue ver sua casa como uma expressão de si, ou expressão de sua identidade, ao contrário de sua barraca, meio de sustento dela e de sua família, que ela descreve como "muito chique". Seu carrinho não é disputado por ninguém, ao contrário de sua casa que abriga incessantes episódios de confronto com os filhos. À barraca, ela consegue conferir uma particularidade, que ela entende como expressão de sua personalidade. Em relação à casa, na qual Patrícia não passa muito tempo, pouco se vê dela, a não ser as garrafas térmicas, os bolos de tabuleiro e pacotes balas que ela leva para vender. Além disso, vê-se a fartura de comida que as crianças têm em casa.

"Gostaria de quando a pessoa chegasse aqui visse um ambiente limpo, um ambiente perfumado, um ambiente... como minha barraca [instrumento de trabalho]. As pessoas chamam minha barraca de lanchonete. Porque eu tenho visão. Até plaquinha tem."

Pelo tempo que ela trabalha, pouco fica em casa com os filhos, o que, segundo ela, prejudica a educação dos filhos. Sua moradia expressa sua rotina, sua carga de trabalho, sua relação com os filhos e vizinhos. A dificuldade que Patrícia alega ter em receber algum auxílio de seus filhos, seja para ajudá-la no trabalho ou para fazer as tarefas domésticas, e, principalmente, o pouco zelo que possuem em relação à moradia da família deixa-a muito chateada. Patrícia reclama, por diversas vezes, que seus filhos não têm cuidado com as coisas dentro de casa, e não compartilham com ela o sentimento de resguardar o espaço doméstico e de restringirem o acesso a todos que quiserem. Mesmo Paola, que por ser "filha mulher", tende a assumir as tarefas domésticas da casa - não a ajuda muito na arrumação. 
Talvez, pelo fato dela ficar tão pouco tempo em casa, Patrícia não consegue estabelecer fronteiras mais fixas, que sejam respeitadas. Claramente, pela postura dos seus filhos, descrita por ela, podemos ver uma disputa pela dominação do espaço. Nem mesmo seu quarto, que é o espaço que ela mais gosta da casa, eles respeitam. A tentativa de demarcar um "território íntimo", a partir de fronteiras físicas, não obteve o sucesso esperado. E o motivo disso, segundo ela, é porque eles não possuem pessoas dedicadas a educá-los: levá-los a escola, ensiná-los bons modos; ou seja, torná-los crianças obedientes e bem educadas. Teoricamente, nenhum deles poderia entrar sem permissão, porém, eles fazem tanta bagunça, que muitas vezes ela fica impossibilitada de dormir em seu próprio quarto. Ela demarca o território, mas não tem condições de dar a esse território as características que ela deseja, pois é constantemente contestado por seus filhos, que passam muito mais tempo do que ela em casa. Em sua fala, podemos perceber uma clara impossibilidade de reforçar essas fronteiras: "Meu quarto é o mais mexido [risos]. Se eu pudesse, nem meus filhos entravam no meu quarto. Era um quarto secreto, pra ninguém entrar" (ver figura 3). Patrícia, assim como os outros moradores, recebeu uma unidade para transformar em seu lar. Ela demonstra em sua fala a vontade de ter uma casa que componha um quarto para seus filhos, porém o que mais aparenta incomodá-la é a falta de privacidade. As paredes de madeira não só incomodam pelo barulho e pela perda da privacidade, por atraírem insetos e terem uma durabilidade muito menor, mas também "enfeiam" a casa. Existem diversas formas de tentar minimizar os efeitos negativos dessas paredes. A forma encontrada por Patrícia foi a colocação de cortinas. Cortinas verdes escuras que escondem toda a parede dos fundos da casa. 


\section{CROQUI DOS ESPAÇOS PRIVADOS \\ Exemplo 2 \\ (2011)}

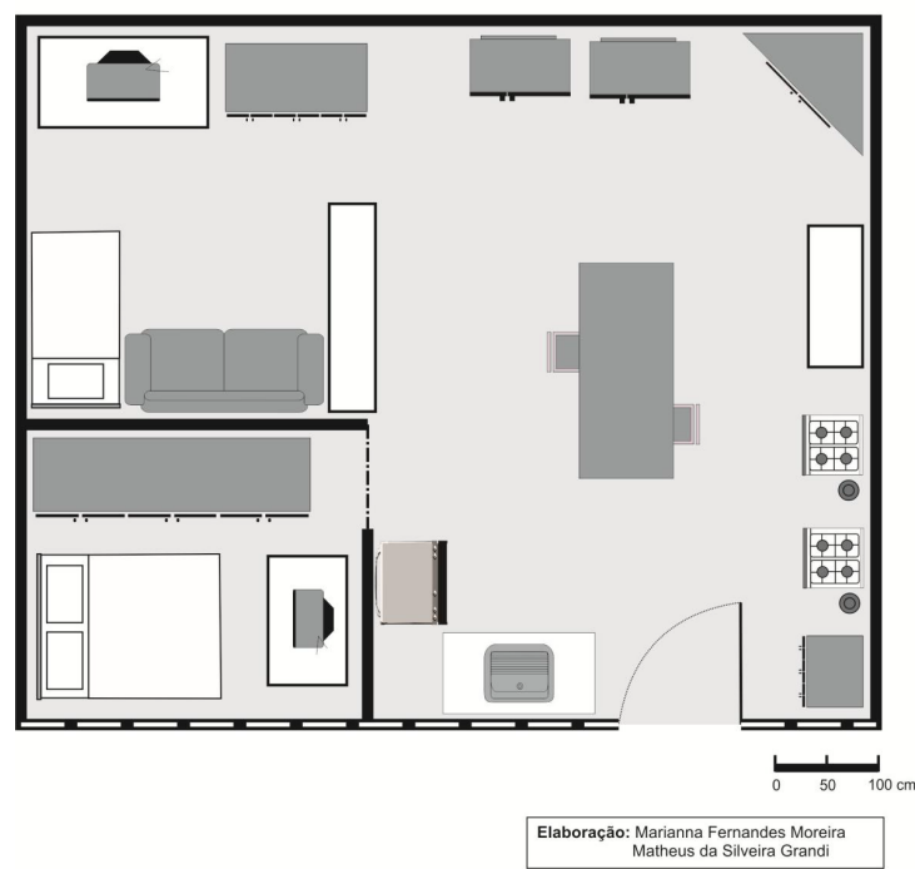

Figura 3

Outro exemplo é o de Ilana, de 37 anos. Ela tem oito filhos e todos moram com ela. A filha mais velha, Silvia, tem dezoito anos e é responsável por praticamente todas as tarefas que envolvem os irmãos menores, desde acordá-los para ir à escola, até alimentá-los e cuidar da sua higiene pessoal. Ilana conta sua experiência difícil na infância. Ela e sua irmã formam morar com as tias, tendo que trabalhar muito para ajudar sua mãe sustentar os irmãos. Talvez seja por essa experiência que mantenha todos seus filhos consigo sem lançar mão, de forma frequente, da "circulação de crianças" ${ }^{12}$, estratégia muito utilizada pelas mulheres das classes populares. Seu filho, Pedro, de quinze anos, por exemplo, foi morar com o padrinho, no bairro de Parada de Lucas, para trabalhar com ele, porém logo depois voltou para casa de sua mãe.

Ilana começou a se relacionar com um morador, recém-chegado. Como Danilo começou sua relação com Ilana após entrar na ocupação, eles moravam em quartos diferentes. Com isso, conseguiam manter a privacidade do casal, ao mesmo tempo em que Ilana estava perto de seus filhos. Seu quarto, nada segmentado (ver figura 4), é um espaço único, sem divisões ou qualquer tipo de separação, o que impossibilita qualquer desejo de privacidade ou intimidade em seu lar. Com isso, Ilana vê-se impossibilitada de constituir um "território 
íntimo" (por mais que esteja no comando) e ela acabou por encontrar seu refúgio, um local mais tranquilo, com mais privacidade, na casa de seu companheiro, é através deste relacionamento que ela constrói um "território íntimo", mesmo que fora de seu espaço doméstico. Lembro-me das vezes em que frequentei a casa de Danilo. Era visível como se sentia a vontade, como se aquele fosse, realmente, seu lar. Era ela que me convidava a entrar, que falava para eu sentar, que me oferecia algo para beber ou comer, e, ele se levantava para buscar e aproveitava para nos deixar a sós. Voltava algum tempo depois. Dava a ela a privacidade, na sala dele, que ela não tinha na casa dela.

Atualmente, ela passa muitas noites fora de casa, pois cuida de um "senhor de idade" e tem que dormir no serviço. E, consequentemente, sua filha Silvia tem que se comprometer com mais tarefas para ajudar sua mãe a cuidar dos irmãos menores. Com poucos objetos em sua casa, a cama de casal é o reduto do chefe da família em exercício. Símbolo que detém um valor que exprime a hierarquia instituída na família. Quando Ilana não dorme em casa, e isso acontece bastante, Silvia, a filha mais velha, se apodera do lugar de referência do comando da casa, se torna a chefa interina e suas regras deverão ser respeitadas. A partir do momento que sua mãe chega, Silvia passa o posto para a Ilana, chefe permanente, e vai dormir na cama de solteiro, até que sua mãe passe a noite fora novamente.

"Funciona como você está vendo aí. Só não pode mexer nos meus ursinhos. Meus ursinhos são prediletos, não vem não. Eu dou banho neles, boto eles pra secar, não quero que ninguém toque neles, não. Mas o resto tá tudo aí, ó. O resto, tudo pode pegar. Ali, ó. Já quebraram o botão da televisão. [...] Tem que tomar banho. Não gosto que eles andem sujos. Não gosto da minha casa suja, fedendo, isso eu não gosto mesmo. $\mathrm{O}$ resto...eu só não quero que caia lá embaixo, o resto deixa rolar. [risos] Eu gostaria de pintar meu quarto, comprar um guarda roupa, uma televisão grande. [...] Eu não gostaria de dividir não. Pra que? Para as crianças quebrarem tudo? Eu só queria ter meu guarda-roupa"

A permeabilidade do espaço doméstico às relações e interações externas a ele, depende de quem está no comando, visto que o território condiciona a acessibilidade. Tais mudanças no condicionamento e permeabilidade das fronteiras do território doméstico, não se 
expressam, no caso, no substrato material. Ilana, quando está presente, reformula as fronteiras de forma clara, simples e direta: a ordem verbal. A delimitação dessas fronteiras se dá a partir de conflitos e negociações. Ao mesmo tempo, podemos perceber uma relação maior de negociação do que de conflito com a sua filha mais velha, até para não deslegitimar a filha perante os outros membros da família. Em consequência disso, não há também muita contestação por parte da filha, esta aceita as regras da mãe com mais facilidade. Ilana não condena, por exemplo, apesar de não gostar, o fato de Silvia deixar crianças do prédio entrarem e brincarem em sua casa. As crianças, que ficam muito tempo sozinhas, transitam pela casa de seus amigos e vice e versa. Diferentemente dos filhos de Patrícia que, segundo ela, são cobrados, mas não correspondem, Silvia acaba tendo direito a algumas regalias. Os deveres são recompensados, pesam nas relações de poder e, consequentemente, vão pesar na configuração territorial do espaço doméstico.

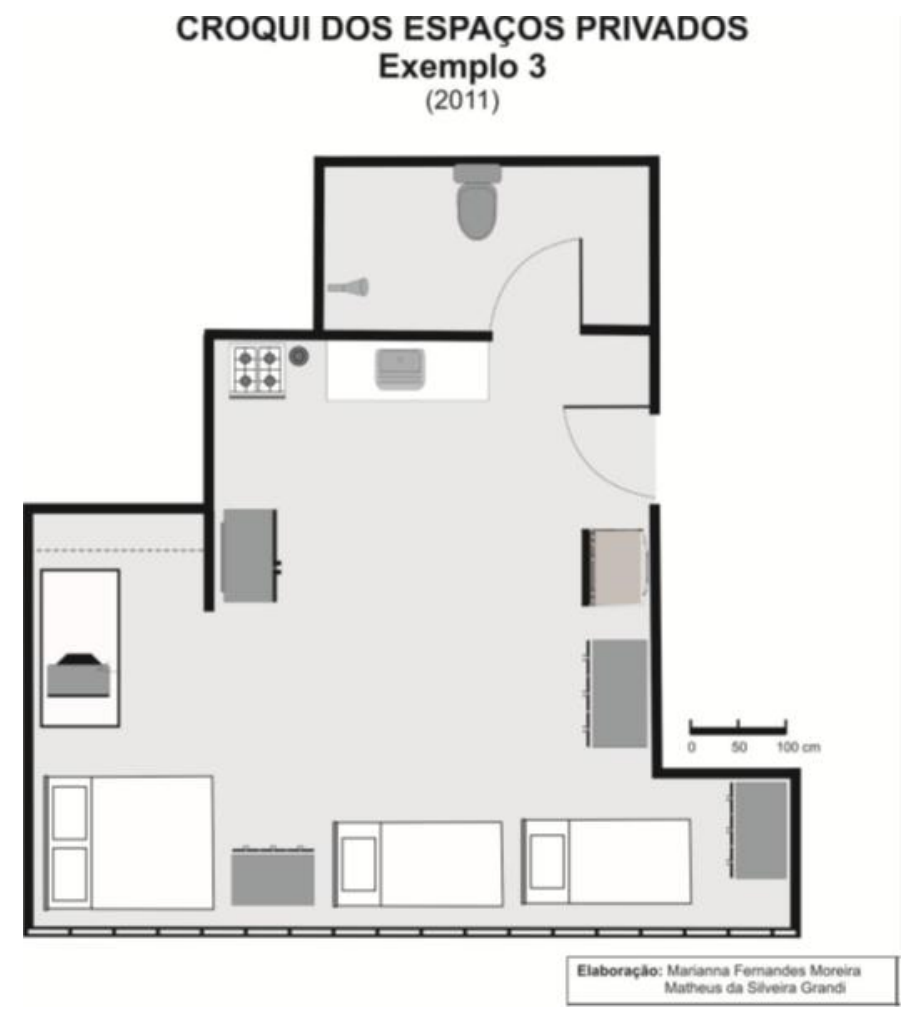

Fig. 1 
Considerações finais

Durante este trabalho busquei discorrer sobre às diversas tensões que se estabelecem nesta forma singular de sociabilidade. A primeira delas é marcada pela relação pouco falada (apesar de latente) entre o Coletivo e o que podemos chamar de família - instituição cuja importância não pode ser esquecida, uma vez que é inegável a relação existente entre ela e o indivíduo. Como já falado acima, a relação indivíduoColetivo é frequentemente permeada pela família, o que permite pensar em uma relação "indivíduo-família-Coletivo". O fato de se tratar de um movimento social, portanto, só nos interessa na medida em que ele age sobre a vida cotidiana dessas mulheres, seja para cobrar mudanças de comportamento, para servir de instrumento de legitimação e controle da mãe sobre seus filhos, ou na construção de relações de ajuda mútua.

As relações sociais e os conflitos projetam-se no espaço, seja através de estratégias territoriais para limitar a mobilidade das crianças, mas também através da subversão da territorialidade imposta. Longe de aceitar passivamente as limitações exigidas pelo Coletivo à sua mobilidade, as crianças desenvolvem suas próprias táticas de transgressão. Além disso, o território da ocupação, em seu movimento de fechamento, e através da vigilância contínua de suas fronteiras, permite que crianças como Marília, transitem livremente pelo prédio, tecendo suas próprias redes de cuidado, sem que sejam diretamente mediadas pelos seus familiares.

Também procurei observar, dentro do espaço doméstico, território da família, como o indivíduo busca um espaço seu e demarca um território ainda mais privado, que delimita uma fronteira clara entre aquele que dele se apossa e nele guarda seus segredos, e aqueles cujo acesso é impedido. Procuro argumentar trabalho que o território íntimo é fruto da transformação das relações de poder no espaço doméstico, que, por sua vez, remetem às transformações que dizem respeito à revalorização da família. Entretanto, as classes populares elaboram as suas próprias táticas e estratégias para constituir territórios íntimos. A partir de alguns casos exemplares, procurei identificar algumas práticas espaciais utilizadas para construção (ou pelo menos a tentativa de construção) de um território íntimo.

Não obstante, o lar não pode ser compreendido apenas em sua dimensão material, pois é, também, um espaço de subjetivação, no qual os discursos de autoridade atuam impondo uma certa 
ordem social, incidindo sobre o comportamento individual: seja através da autoridade da mãe sobre o filho; seja através da autoridade de um amigo da família - que exige, por exemplo, a correção do comportamento materno no sentido de cuidar melhor dos filhos, manter a casa limpa, protegê-los da sexualidade adulta etc.; seja através da autoridade do filho sobre a mãe - exigindo carinho e proteção (respaldado, inclusive, pelas normas formais que emanam da autoridade estatal); ou das instituições do Estado, que mantêm a vigilância e atuam de forma assistencialista (oferecendo ajuda em troca de novos hábitos e comportamentos), ou ainda de forma punitiva (desmembrando a família e colocando-a sub sua tutela). Assim, mais do que um abrigo, o lar é um espaço de produção subjetiva, é território e lugar de construção identitária.

Portanto, busquei mostrar como as resistências, os conflitos e as linhas de fuga, ora legitimam e reforçam as regras do "jogo", elaborando, eles mesmos, novas estratégias para adaptar tais regras às condições em que se encontram; e ora questionam, recusam e contornam a norma através de seus interstícios e de seus disfuncionamentos. Precisamos ter, assim como os sem-teto, um trajeto oscilante, de vai e vem contínuo, mas que parte sempre, por escolha metodológica, dos momentos de tensão e negociação, em que a normalização encontra o desvio e a resistência.

\section{NOTAS}

\footnotetext{
${ }^{1}$ Agradeço a Rafael Gonçalves de Almeida pela leitura crítica e revisão deste artigo, e por suas sugestões e referências.

${ }^{2}$ Doutoranda do Programa de Pós-graduação em Geografia da Universidade Federal do Rio de Janeiro e pesquisadora do Núcleo de Pesquisas sobre Desenvolvimento Sócio-Espacial / NuPeD, coordenado pelo Prof. Dr. Marcelo Lopes de Souza

${ }^{3}$ Cf. MOREIRA, Marianna Fernandes. GRANDI, Matheus da Silveira. ALMEIDA, Rafael Gonçalves (2009): Xadrez Urbano: Uma Introdução às Peças e Estratégias Espaciais do Movimento dos Sem-Teto. Brasília: Anais do XI SIMPURB.

${ }^{4}$ Depoimento prestado em 02 de fevereiro de 2011 por Adelaide (moradora da Ocupação Quilombo das Guerreiras). Entrevista realizada por Marianna Fernandes Moreira.

${ }^{5}$ Depoimento prestado em 28 de junho de 2010 por Patrícia (moradora da Ocupação Quilombo das Guerreiras). Entrevista realizada por Marianna Fernandes Moreira.

${ }^{6}$ Depoimento prestado em 30 de maio de 2011 por moradora da Ocupação Quilombo das Guerreiras. Entrevista realizada por Marianna Fernandes Moreira

${ }^{7}$ Depoimento prestado em 02 de fevereiro de 2011 por Adelaide (moradora da Ocupação Quilombo das Guerreiras).
}

\footnotetext{
Entrevista realizada por Marianna Fernandes Moreira.

${ }^{8}$ Depoimento prestado em 16 de maio de 2011 por moradora da Ocupação Quilombo das Guerreiras. Entrevista realizada por Marianna Fernandes Moreira.

${ }^{9}$ Para um aprofundamento sobre o tema ver MOREIRA, Marianna Fernandes (2011) "Um Palacete Assobradado": Da reconstrução do lar (materialmente) à reconstrução da ideia de "lar" em uma ocupação de sem-teto no Rio de Janeiro. Dissertação (Mestrado em Geografia). Programa de Pós-Graduação em Geografia /UFRJ, Rio de Janeiro.

${ }^{10}$ Marcelo Lopes de Souza. Souza ressalta que o território não pode ser encarado como um sinônimo do substrato material que lhe serve de suporte, pois esse pode se constituir e se desfazer sem que, necessariamente, deixe marcas na paisagem. Isso não significa, porém, que território e o seu substrato possam ser separados concretamente. Souza compreende o território como um campo de forças, ou seja, "relações de poder espacialmente delimitadas e operando, destarte, sobre um substrato referencial" (SOUZA, 2007 [1995], p. 97).

${ }^{11}$ Ibdem.
} 
${ }^{12}$ Este termo é utilizado para designar "toda transação pela qual a responsabilidade de uma criança é transferida de um adulto para outro" (Fonseca, 1995, p. 116). Indica que a transferência de uma criança entre diferentes famílias (parentes ou não) acontece de forma parcial e temporária.

\section{REFERÊNCIAS BIBLIOGRÁFICAS}

ARIÈS, Philippe. História social da criança e da família. Rio de Janeiro: Guanabara, 1981.

(2009). "Por uma história da vida privada". In: História da vida privada 3: Da Renascença ao Século das Luzes. São Paulo: Companhia das Letras.

BLUNT, Alison \& DOWLING, Robyn (2006). Home. London: Routledge.

BOTT, Elizabeth (1976 [1971]). Familia e rede social. Mário Guerreiro (tradução). Alba Zaluar Guimarães (revisão técnica). Rio de Janeiro: Francisco Alves.

BUNGE William \& BORDESSA, Robert (1975) The Canadian Alternative: Survival, Expedidtions and Urban Change. Geographical Monographs $n^{\circ}$ 2. New York: New York University.

BUTLER, Judith. (2003) Problemas de Gênero: feminismo e subversão da identidade. Rio de Janeiro: Civilização Brasileira.

CAPEL, Horacio. (1981). Filosofía y ciência em la geofrafía contemporanéa. Barcelona: Barcanova.

DE CERTEAU, Michel (2008 [1996]). A invenção do Cotidiano: 1. Artes de fazer. Ephaim Ferreira Alves (tradução). Petrópolis: Editora Vozes. $14^{\mathrm{a}} \mathrm{ed}$.

DONZELOT, Jacques. (1986 [1980]) A Polícia das Famílias. M. T. da Costa Albuquerque (tradução). J. A. Guilhon Albuquerque (revisão técnica). Rio de Janeiro: Graal, $2^{\circ}$ ed.

DUARTE, Luiz Fernando Dias (1995). "Horizontes do indivíduo e da ética no crepúsculo da família". In: RIBEIRO, Ivete \& RIBEIRO, Ana Clara Torres (orgs.). Família em processos contemporâneos : inovações culturais na sociedade brasileira. São Paulo: Loyola.

FONSECA, Claudia (1995). "Amor e Família: vacas sagradas da nossa época". In: RIBEIRO, Ivete \& RIBEIRO, Ana Clara (orgs.). Família em processos contemporâneos: inovações culturais na sociedade brasileira. São Paulo: Loyola

(2004 [2000]). Família, fofoca e honra: etnografia de relações de gênero e violência em grupos populares. Porto Alegre: Editora da UFRGS. $2^{\mathrm{a}}$ ed.

(2007). "Ser mãe, mulher e pobre". In: PRIORE, Mary Del (org.) História das Mulheres no Brasil. São Paulo: Contexto. $8^{\text {a }} \mathrm{ed}$.

FOUCAULT, Michel (1993 [1976]). A história da sexualidade 1: $A$ vontade de saber. Rio de Janeiro: Graal
(2007 [1975]): Vigiar e punir: História da violência nas prisões. Petrópolis: Vozes.

(2008 [1978]): Segurança, território, população. São Paulo: Martins Fontes.

GUATARRI, Félix (1985): Revolução Molecular: Pulsões políticas do desejo. São Paulo: Brasiliense. $2^{\mathrm{a}}$ ed.

GUATARRI, Félix \& ROLNIK, Suely (2005 [1986]): Micropolítica: Cartografias do Desejo. São Paulo: Brasiliense.

HOOKS, bell (1991). Yearning: Race, Gender, and Cultural Politics. London: Turnaround.

MELLO, Sylvia Leser de (2003 [1995]) "Família: perspectiva teórica e observação factual". In: CARVALHO, Maria do Carmo Brant de (org.). A família contemporânea em debate. São Paulo: EDUC/Cortez.

MOREIRA, Marianna Fernandes (2011) "Um Palacete Assobradado": Da reconstrução do lar (materialmente) à reconstrução da ideia de "lar" em uma ocupação de sem-teto no Rio de Janeiro. Dissertação (Mestrado em Geografia). Programa de Pós-Graduação em Geografia /UFRJ, Rio de Janeiro.

MOREIRA, Marianna Fernandes. GRANDI, Matheus da Silveira. ALMEIDA, Rafael Gonçalves (2009): Xadrez Urbano: Uma Introdução às Peças e Estratégias Espaciais do Movimento dos Sem-Teto. Brasília: Anais do XI SIMPURB.

RELPH, Edward (1980[1976]): Place and placelessness. Londres: Pion.

ROSE, Gillian (1993) Feminism \& geography: the limits of geographical knowledge. Cambridge: Polity Press

SARTI, Cynthia A. (1995). "O valor da família para os pobres". In: RIBEIRO, Ivete \& RIBEIRO, Ana Clara (orgs.) Família em processos contemporâneos: inovações culturais na sociedade brasileira. São Paulo: Loyola

(2003[1995]) "Família e individualidade: um problema moderno". In: CARVALHO, Maria do Carmo B. (Org.). A família contemporânea em debate. São Paulo: EDUC, 1995. p.39-49.

(2009) A família como espelho: um estudo sobre a moral dos pobres. São Paulo: Cortez.

SERFATY-GARZON, Perla. (2003): Chez soi: Les territoire de l'intimité. Paris: Armand Coulin.

SIMMEL, Georg. (2005[1903]): "As grandes cidades e a vida do espírito". In: Mana - Estudos de Antropologia Social. V. $11 \mathrm{n}^{\mathrm{o}} 2$, out., pp. 577-591.

(1964). "Conflict". In Conflict and the Web of Group Affiliations. NY/London: The Free Press/MacMillan Publishers, 1964. pp 11-123

SZYMANSKI, Heloisa. (2003 [1995]). "Teoria e Teorias de famílias". In: CARVALHO, Maria do Carmo Brant de (org.). A família contemporânea em debate. São Paulo: EDUC/Cortez.

TOREN, Cristina (1999). "Compassion for one another: constituting kinship as intentionality in Fiji". In: 
Journal of the Royal Anthropological Institute 5: 265 -

280

VIANNA, Adriana de Resende Barreto (2002) Limites da menoridade : tutela, família e autoridade em julgamento. Tese de Doutorado submetida ao Programa de Pós-graduação em Antropologia Social

do Museu Nacional/UFRJ. Rio de Janeiro

HOME AND FAMILY IN GEOGRAPHY: SPATIAL STRATEGIES OF THE "SEM-TETO" WOMEN IN THE HOME CONSTRUCTION

ABSTRACT: THIS ARTICLE FOCUSES ON A VERY PECULIAR COLLECTIVE DWELLING: AN URBAN SQUAT CALLED QUILOMBO DAS GUERREIRAS, LOCATED IN THE CENTRE OF THE CITY OF RIO DE JANEIRO. THE PROPOSED APPROACH AIMS TO ADDRESS THE GEOGRAPHY OF HOME AND FAMILY THROUGH THE SPATIAL STRATEGIES AND PRACTICES OF THE "SEM-TETO" WOMEN IN THE CONSTRUCTION OF THEIR HOME. IN THE FIRST PART OF THE PAPER, I DISCUSS THE FAMILY AS A MECHANISM OF GOVERNMENT AND THE PARTICULARITIES OF THE EXERCISE OF POWER OVER THE LOWER CLASSES. I THEN SEEK TO ADDRESS THE INDIVIDUAL-FAMILYCOLLECTIVE TENSIONS THAT EMERGE, HIGHLIGHTING THE SPECIFIC CHARACTERISTICS OF A SOCIAL MOVEMENT SUSTAINED BY ALLEGIANCES WOVEN BY EMOTIONAL BONDS AND COMMUNITARIAN SOCIAL RELATIONS THAT PERMEATE PRIVATE SPACES, FAMILY LIFE AND CHILD CARE. FINALLY, I ADDRESS THE MATERIAL CONSTRUCTION OF THE HOUSEHOLD AND THE SPATIAL PRACTICES THAT CONSTITUTE, IN DIFFERENT WAYS, AN "INTIMATE TERRITORY" IN WHICH THE INDIVIDUALITY OF THE WOMEN CAN BE EXPRESSED.

KEYWORDS: SQUATIING, HOUSE, FAMILY, INTIMATE TERRITORY, FEMINIST GEOGRAPHY

HOGAR Y FAMILIA EN GEOGRAFÍA: ESPACIAL ESTRATEGIAS DE LA MUJER "SEM-TETO" EN LA CONSTRUCCIÓN DEL HOGAR

RESUMEN: ESTE ARTíCULO SE CENTRA EN UNA MORADA PECULIAR COLECTIVA: UNA OCUPACIÓN DE PERSONAS "SEM-TETO" LLAMADO OCUPAÇ̃̃O QUILOMBO DAS GUERREIRAS. El ENFOQUE PROPUESTO TIENE COMO OBJETIVO ABORDAR LA GEOGRAFÍA DEL HOGAR Y LA FAMILIA DESDE LAS ESTRATEGIAS ESPACIALES Y PRÁCTICAS DE LAS MUJERES "SEM-TETO" EN LA CONSTRUCCIÓN DE LA CASA. EN LA

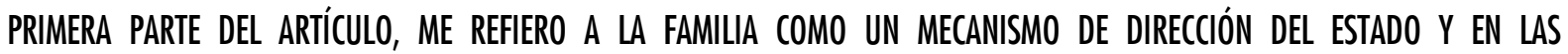
PARTICULARIDADES DEL EJERCICIO DEL PODER SOBRE LAS CLASES BAJAS. El PROPÓSITO DE ESTA PARTE ES PROBLEMATIZAR LA 
NOCIÓN DE FAMILIA NUCLEAR Y SEÑLLAR CÓMO LA INTERVENCIÓN DEL ESTADO EN MATERIA DE VIVIENDA DE LOS POBRES URBANOS SERÁ UNA MANERA DE INDUCIR DETERMINADOS COMPORTAMIENTOS Y HÁBITOS PARA PROMOVER El ESTABLECIMIENTO DE UNA FAMILIA NUCLEAR. A CONTINUACIÓN VOY A TRATAR DE HACER FRENTE A LA TENSIÓN FAMILIA-COLECTIVO-INDIVIDUO EMERGENTE, PUNTUANDO LAS CARACTERISTICAS ESPECÍFICAS DE UN MOVIMIENTO QUE ESTÁ SOSTENIDO POR LAS ALIANZAS TEIDAS POR LOS LAZOS DE AFECTIVIDAD Y LAS RELACIONES SOCIALES COMUNITARIAS QUE IMPREGNAN LOS ESPACIOS PRIVADOS, LA VIDA FAMILIAR Y EL CUIDADO DE NIÑOS. POR ÚLTIMO, ME DIRIJO LA ATENCIÓN SOBRE EL MATERIAL DE CONSTRUCCIÓN DE LA CASA Y LAS PRÁCTICAS ESPACIALES QUE CONSTRUYEN DE DIFERENTES MANERAS, UN "ESTRECHO TERRITORIO" EN EL QUE LA INDIVIDUALIDAD DE LA MUJER PUEDE EXPRESARSE A SÍ MISMA MÁS ALLÁ DEL ESPACIO DOMÉSTICO.

PALABRAS CLAVE: SIN HOGAR, CASA, FAMILIA, HOGAR, TERRITORIO ÍNTIMO, GEOGRAFÍA FEMINISTA. 